\title{
PROXIMATE ANALYSIS AND AMINOACID PROFILES OF LEAVES, FLOWERS, PODS, AND SEEDS OF ERYTHRINA EDULIS FROM PERU
}

\author{
ADELMO PARRAGA ${ }^{1}$, JAVIER GONZALES ${ }^{1}$, ROSARIO PORTALES ${ }^{2}$, CANDY RUIZ², ROSARIO ROJAS ${ }^{2}$ \\ ${ }^{1}$ Universidad Daniel Alcides Carrion, Pasco, Peru, ${ }^{2}$ Unidad de Investigacion en Productos Naturales, Laboratorios de Investigacion y \\ Desarrollo, Facultad de Ciencias y Fisolosofia, Universidad Peruana Cayetano Heredia, Lima, Peru \\ Email: rosario.rojas@upch.pe
}

Received: 20 Nov 2020, Revised and Accepted: 13 Feb 2021

\section{ABSTRACT}

Objective: The study aim was to determine the proximate composition and amino acid profiles of seeds, leaves, pods, and flowers of Erythrina edulis that are consumed in Oxapampa, Perú.

Methods: Plant parts of E. edulis were analyzed for proximate composition (proteins, carbohydrates, fat, fiber, and ash) according to AOAC methods. Amino acid profiles were determined by HPLC analysis.

Results: Fat contents were low $(<1.3 \%)$ in all four plant parts. The crude fiber was high in leaves and pods $(19.9$ and $15.1 \%$, respectively). Protein contents in leaves $(24.4 \%)$ and flowers $(23.7 \%)$ were higher than that of the pods $(19.3 \%)$. The limiting amino acids in the seeds were methionine and tryptophan, while the pods were deficient in four amino acids (methionine, tryptophan, histidine, and isoleucine). Of the four plant parts studied, the flowers turned out to be a promising source of protein because they meet most of the amino acid requirements for adults recommended by FAO.

Conclusion: The seeds and flowers of $E$. edulis have a high protein content and a good amino acid profile that makes them recommended for human consumption.

Keywords: Amino acids, Erythrina edulis, Proximate analysis

(C) 2021 The Authors. Published by Innovare Academic Sciences Pvt Ltd. This is an open access article under the CC BY license (https://creativecommons.org/licenses/by/4.0/) DOI: https://dx.doi.org/10.22159/ijpps.2021v13i4.40312. Journal homepage: https://innovareacademics.in/journals/index.php/ijpps.

\section{INTRODUCTION}

Erythrina edulis is one of the about 112 legume species belonging to the genus Erythrina [1]. The name of the genus comes from erythros, which means red in reference to the color of its flowers [2]. It is the only species with edible seeds and is widely cultivated in the highlands of the Andes from Venezuela to Bolivia as living fenceposts and to provide food for humans and domestic animals [3]

E. edulis is a tree that reaches $8-15 \mathrm{~m}$ in height and $24-45 \mathrm{~cm}$ in diameter, its fruit is a pod that measures $15-50 \mathrm{~cm}$ long, with 8-12 seeds per pod $[4,5]$.

This legume is distributed in tropical and subtropical areas of South America, in Peru it grows at altitudes of 900 to 3,200 meters above sea level, presenting for these reasons numerous vernacular names such as Sacha poroto, Inca bean, basul, pashuro, poroto, balú, chachafruto, among others [6, 7]

E. edulis is a perennial tree, long-lived (average $140 \mathrm{y}$ ), and multipurpose. It is a notable nitrogen fixer, controls soil erosion, and provides nectar from its abundant flowers. This species is one of the easiest trees to grow, does not require special care or phytosanitary treatment, and withstands long periods of drought. Sections of stem take root readily and become living and long-lasting fence posts. It can also be used for shading coffee, cocoa, and other sun-sensitive crops $[6,8]$.

This tree blooms in dark red and orange-red clusters 30-45 centimeters long and each cluster has an average of 190 flowers. The pods can have 8 to 12 dark brown kidney-shaped seeds, with two greenish-white cotyledons $3.5-7 \mathrm{~cm}$ long by 2-3 cm in diameter [9].

The leaves and immature pods of this legume are used to feed cattle, pigs, sheep, guinea pigs, and chickens [10]. The flowers are very beautiful so the tree can have an ornamental use. The flowers can also be used in salads and sweets and infusions taken for anxiety and urinary problems [9]. The large seeds are usually boiled in water with salt and are served as a side dish to corn, cassava, bread, or potatoes. The seeds are also consumed in the form of cake or dessert and the pods are sometimes used in the preparation of pickles [11, 12]. The seeds contain a high amount $(18-25 \%)$ of proteins with high digestibility and quality higher than that of other legumes $[6,8,11]$.

Although the use of different parts of the species E. edulis in human and animal nutrition is well known, their nutritional composition and amino acid profiles are not known in detail. The objective of the present work is to determine the proximal composition (proteins, fats, fiber, carbohydrates, and ashes) and the amino acid profiles of the seeds, pods, leaves, and flowers of E. edulis from Oxapampa, Peru, for a comprehensive benefit of this natural resource.

\section{MATERIALS AND METHODS}

\section{Chemicals and reagents}

All reagents and chemicals were of analytical grade. Amino acid standards, trifluoroacetic acid, and 2-mercaptoethanol were purchased from SIGMA-Aldrich; monobasic phosphate from MERCK, hydrochloric acid, methanol, acetonitrile, sodium bicarbonate, and milli-Q-Water. All reagents and solvents used were of analytical grade and HPLC grade respectively.

\section{Plant material}

The vegetable material was collected in Pozuzo, Pasco, Peru. Plant material was identified by one of us (A. P.), and a voucher specimen under the accession number Ee-126 was deposited at HOXA, Oxapampa, Peru (a Peruvian affiliate of the Missouri Botanical Garden, MO, USA). Samples were taken from seeds, leaves, pods, and flowers. Each sample was analyzed after the stove drying.

\section{Proximate analysis}

The proximal analyses of samples were performed according to the methodology established in AOAC 2010 [13]. Moisture contents of the samples were determined during desiccation at $105{ }^{\circ} \mathrm{C}$ until a constant weight was reached. Total fat was extracted in Soxhlet extractor with petroleum ether. Protein content was calculated by converting the nitrogen content determined by Kjeldahl ( $\mathrm{N}$ x-factor 
of 6.25). The total fiber was analyzed with alkaline and acid digestion, and the ash content was determined by incineration in a muffle furnace at $550{ }^{\circ} \mathrm{C}$. Carbohydrate content was calculated as difference using protein, lipid, fiber, and ash content data.

\section{Amino acid profile}

Five milligrams of the defatted sample were hydrolyzed in a mixture of trifluoroacetic acid and $\mathrm{HCl} 6 \mathrm{~N} \mathrm{(1:2)}$ and 2-mercaptoethanol at $166{ }^{\circ} \mathrm{C}$ for 25 min. For amino acid derivatization, the solution was dried and dissolved in $1 \mathrm{ml}$ of $\mathrm{NaHCO}_{3}(0.15 \mathrm{M})$ buffer [14].

Derivatization of amino acids was carried out according to Ribeiro et al. [15], with some modifications. Dabsyl chloride was dissolved in acetonitrile and then filtered and store at- $20^{\circ} \mathrm{C}$. The elution buffer consisted of a solution of potassium phosphate acid $0.025 \mathrm{M}, \mathrm{pH} 6$. A dilution buffer was prepared by mixing $50 \mathrm{ml}$ of ethanol and $50 \mathrm{ml}$ elution buffer.

$260 \mu \mathrm{l}$ of dabsyl chloride solution (12.4 mmol) was added to aliquots of $160 \mu$ of standard solution or hydrolyzed solution. The vials were mixed and incubated at $70{ }^{\circ} \mathrm{C}$ for $10 \mathrm{~min}$, the reaction was stopped by placing the vials in an ice bath for $5 \mathrm{~min}$. $580 \mu \mathrm{l}$ of dilution buffer was added followed by mixing and centrifugation $(5 \mathrm{~min}$ at 5000 $\mathrm{rpm}$, the clear supernatants were filtered and placed in $1 \mathrm{ml}$ vials.
A reversed-phase supelcosil TMLC-DABS column $(15 \times 4.6 \mathrm{~cm}$; particle size $3 \mu \mathrm{m}$ ) was used. Two eluents were used as the mobile phase: elution buffer (A) and $80 \%$ acetonitrile (B). Elution was performed at a flow rate of $1 \mathrm{ml} / \mathrm{min}$, starting with $25 \% \mathrm{~B}$ up to 10 min and installing a gradient to obtain $35 \%$ B at $35 \mathrm{~min}, 50 \% \mathrm{~B}$ at 45 min and $100 \%$ from B at $56 \mathrm{~min}$, keeping $100 \%$ B up to $66 \mathrm{~min}$. Detection was accomplished with a UV-vis detector at $436 \mathrm{~nm}$. Quantification of free amino acids was achieved using the absorbance recorded in the chromatograms in relation to the external standards.

\section{RESULTS AND DISCUSSION}

The chemical compositions of seeds, leaves, pods, and flowers of $E$. edulis are shown in table 1 . Fat contents were low $(<1.3 \%)$ in all four plant parts. The crude fiber was high in leaves and pods (19.9 and $15.1 \%$, respectively). Fiber helps prevent and control cardiovascular disease by reducing total and low-density lipoprotein (LDL) cholesterol levels. It also helps regulate blood sugar levels and is beneficial from a nutritional point of view, since fiber helps the absorption of trace elements in the intestine [16]. The ash content in leaves, pods, and flowers was high $(<9 \%)$, which could indicate that the plant is rich in minerals that can contribute a substantial amount of minerals to our diet [17].

Table 1: Proximate analysis of seeds, leaves pods, and flowers of Erythrina edulis ${ }^{\text {a }}$

\begin{tabular}{|c|c|c|c|c|}
\hline \multirow[t]{2}{*}{ Parameter } & \multicolumn{4}{|c|}{ Percentage (\%) } \\
\hline & Seeds & Leaves & Pods & Flowers \\
\hline Fat & $0.3 \pm 0.1$ & $0.6 \pm 0.0$ & $0.9 \pm 0.1$ & $1.3 \pm 0.0$ \\
\hline Ash & $5.5 \pm 0.1$ & $9.6 \pm 0.1$ & $12.8 \pm 0.3$ & $14.1 \pm 0.5$ \\
\hline Crude Protein & $26.4 \pm 1.2$ & $24.4 \pm 0.7$ & $19.3 \pm 0.1$ & $23.7 \pm 0.8$ \\
\hline Crude Fiber & $7.5 \pm 0.7$ & $19.9 \pm 0.3$ & $15.1 \pm 0.6$ & $10.6 \pm 0.1$ \\
\hline Total Carbohydrate & $60.2 \pm 1.4$ & $45.6 \pm 0.6$ & $51.9 \pm 0.5$ & $50.3 \pm 1.2$ \\
\hline
\end{tabular}

aValues are the means of three determinations $\pm \operatorname{SD}(n=3)$.

The seeds have high contents of carbohydrates $(60.2 \%)$ and protein $(26.4 \%)$. Other studies reported protein values ranging from $18 \%$ to $26.2 \%[6,10,18]$. The content of protein in the pods in the studied sample (19.3\%) is similar to those found by Arango et al. [18] and Barrera and Mejía [10] (18.4\% and 21.0\%, respectively). Protein contents in leaves $(24.4 \%)$ and flowers $(23.7 \%)$ were higher than that of the pods $(19.3 \%)$. No previous reports were found for protein contents in leaves and flowers of $E$. edulis.

The limiting amino acids in the seeds were methionine and tryptophan, while the pods were deficient in four amino acids (methionine, tryptophan, histidine, and isoleucine). The flowers were deficient only in histidine (13.2 $\mathrm{mg} / \mathrm{g}$ protein).

Table 2: Amino acid profiles of seeds, leaves pods, and flowers of Erythrina edulis ${ }^{\text {a }}$

\begin{tabular}{|c|c|c|c|c|c|}
\hline \multirow[t]{2}{*}{ Aminoacid } & \multicolumn{4}{|c|}{ mg/g protein } & \multirow[t]{2}{*}{ FAO $^{4}$} \\
\hline & Seeds & Leaves & Pods & Flowers & \\
\hline \multicolumn{6}{|c|}{ Essential amino acids } \\
\hline Phenylalanine & $39.2 \pm 0.9$ & $35.8 \pm 1.4$ & $25.0 \pm 1.0$ & $91.1 \pm 2.9$ & $19^{b}$ \\
\hline Histidine & $22.5 \pm 1.1$ & $5.6 \pm 0.3$ & $1.4 \pm 0.1$ & $13.2 \pm 1.0$ & 16 \\
\hline Isoleucine & $16.1 \pm 0.9$ & $15.2 \pm 1.6$ & $5.1 \pm 0.5$ & $31.2 \pm 1.9$ & 13 \\
\hline Leucine & $52.3 \pm 2.7$ & $63.9 \pm 1.3$ & $35.2 \pm 1.0$ & $35.5 \pm 1.2$ & 19 \\
\hline Lysine & $47.1 \pm 1.6$ & $56.1 \pm 1.7$ & $22.2 \pm 0.6$ & $77.8 \pm 2.7$ & 16 \\
\hline Methionine & $10.0 \pm 0.4$ & $14.7 \pm 0.3$ & $8.4 \pm 0.7$ & $19.4 \pm 0.2$ & $17^{\mathrm{c}}$ \\
\hline Threonine & $18.0 \pm 1.1$ & $22.3 \pm 1.0$ & $12.2 \pm 1.0$ & $30.8 \pm 2.1$ & 9 \\
\hline Tryptophan & $4.9 \pm 0.0$ & $7.5 \pm 0.8$ & $4.3 \pm 0.5$ & $13.8 \pm 1.0$ & 5 \\
\hline Valine & $13.3 \pm 0.4$ & $16.4 \pm 0.4$ & $13.6 \pm 1.2$ & $22.7 \pm 1.2$ & 13 \\
\hline \multicolumn{6}{|c|}{ Non-essential amino acids } \\
\hline Alanine & $40.0 \pm 3.7$ & $52.1 \pm 0.9$ & $28.0 \pm 1.0$ & $55.5 \pm 1.6$ & \\
\hline Arginine & $35.3 \pm 2.3$ & $30.4 \pm 0.6$ & $36.1 \pm 0.9$ & $29.7 \pm 1.7$ & \\
\hline Asparagine & $2.9 \pm 0.0$ & $4.8 \pm 0.0$ & $2.7 \pm 0.1$ & $6.1 \pm 0.3$ & \\
\hline Aspartic acid & $63.6 \pm 1.3$ & $53.2 \pm 0.2$ & $32.0 \pm 0.5$ & $48.3 \pm 1.0$ & \\
\hline Cysteine & $5.7 \pm 0.2$ & $5.8 \pm 0.0$ & $2.6 \pm 0.1$ & $11.1 \pm 1.1$ & \\
\hline Glutamic acid & $53.5 \pm 0.5$ & $47.9 \pm 0.2$ & $26.6 \pm 1.3$ & $42.5 \pm 1.3$ & \\
\hline Glutamine & $4.9 \pm 0.2$ & $14.4 \pm 1.2$ & $8.8 \pm 0.8$ & $10.5 \pm 2.1$ & \\
\hline Glycine & $47.1 \pm 1.5$ & $47.5 \pm 1.7$ & $29.4 \pm 0.5$ & $59.5 \pm 2.3$ & \\
\hline Proline & $30.9 \pm 1.3$ & $25.5 \pm 1.1$ & $24.9 \pm 1.4$ & $27.3 \pm 2.7$ & \\
\hline Serine & $35.7 \pm 1.3$ & $64.7 \pm 2.2$ & $24.9 \pm 0.1$ & $49.0 \pm 2.5$ & \\
\hline Tyrosine & $12.3 \pm 0.2$ & $9.6 \pm 0.5$ & $5.0 \pm 0.3$ & $14.5 \pm 0.7$ & \\
\hline
\end{tabular}

aValues are the means of three determinations $\pm \mathrm{SD}(\mathrm{n}=3)$., ${ }^{\mathrm{P}}$ Phenylalanine+tyrosine; $\mathrm{c}$ Methionine+cysteine 
According to Morales A. [19], the biological quality of proteins from $E$. edulis is superior to that of beans, lentils, peas, or chickpea. The biological value of the pajuro protein is $70.9 \%$ and, compared to other legumes such as lentil (44\%), beans (58\%), or peas $(63.7 \%)$, is much higher, as mentioned by Acero [11].

The results are consistent with those reported by D'Amore [20], the seeds of Erythrina edulis comply with most of the amino acids required by the FAO except for methionine and tryptophan (10 and $4.9 \mathrm{mg} / \mathrm{g}$ of protein, respectively). Intiquilla et al. reported that in the seeds of E. edulis only four amino acids (histidine, leucine, lysine, and valine) meet the requirements. It should be mentioned that the values found by Intiquilla et al. are lower than those reported by us, except for histidine whose value is similar to $22 \mathrm{mg} / \mathrm{g}$ protein.

The most abundant essential amino acids in the seeds were leucine and lysine (52.3 and $47.1 \mathrm{mg} / \mathrm{g}$ of protein, respectively). Aspartic acid and glutamic acid were the major non-essential amino acids ( 63.6 and $53.5 \mathrm{mg} / \mathrm{g}$ protein, respectively), these findings were similar to those reported by Intiquilla et al. [21].

In the literature, no reports have been found of the amino acids present in the leaf, pods, and flowers. Thus, in the case of the leaves, they only present two deficient amino acids (histidine and methionine) concerning the requirements reported by the FAO for adults.

The most abundant essential amino acids in the leaves were leucine and lysine with values of 63.9 and $56.1 \mathrm{mg} / \mathrm{g}$ of protein, respectively, while aspartic acid and serine were the major non-essential amino acids (53.2 and $64.5 \mathrm{mg} / \mathrm{g}$ protein, respectively).

The chemical score referred to the FAO of the pods was evaluated observing that they are deficient in four amino acids: histidine (1.4 $\mathrm{mg} / \mathrm{g}$ protein), isoleucine $(5.1 \mathrm{mg} / \mathrm{g}$ protein), methionine $(8.4 \mathrm{mg} / \mathrm{g}$ protein), and tryptophan (4.3 $\mathrm{mg} / \mathrm{g}$ protein).

The most abundant essential amino acids present in the pods were leucine and phenylalanine (35.2 and $25.0 \mathrm{mg} / \mathrm{g}$ of protein, respectively). Aspartic acid and serine were the non-essential amino acids with the highest quantity, with values of 32.0 and $36.1 \mathrm{mg} / \mathrm{g}$ protein, respectively.

Regarding flowers, only histidine ( $13.2 \mathrm{mg} / \mathrm{g}$ protein) is deficient according to its chemical score referred by the FAO. The most abundant essential amino acids were phenylalanine and lysine (91.1 and $77.8 \mathrm{mg} / \mathrm{g}$ protein). The major non-essential amino acids were glycine and alanine (53.2 and $64.5 \mathrm{mg} / \mathrm{g}$ protein, respectively).

Erythrina edulis is a native species that, despite its high protein and good amino acid profile, is being underestimated and underexploited. Like other indigenous crops, E. edulis is in danger of being replaced by other cultivated species and of suffering continuous genetic erosion, putting at risk a food resource of local populations [22].

\section{CONCLUSION}

The protein contents of seeds, pods, leaves, and flowers of Erythrina edulis were $26.4,19.3,24.4$, and $23.7 \%$, respectively. Of the four plant parts studied, the flowers turned out to be a promising source of protein because it meets most of the amino acid requirements for adults recommended by FAO. The limiting amino acids in the seeds were methionine and tryptophan, while the pods were deficient in four amino acids (methionine, tryptophan, histidine, and isoleucine).

\section{FUNDING}

Nil

\section{AUTHORS CONTRIBUTIONS}

A. P. conceived the project and identified the plant specimen; J. G. collected the plant material and drafted the manuscript; R. P. carried out the proximate analysis and interpreted the data; C. R. determined the amino acid profiles of plant samples and analyzed the results; R. R. planned and directed the project, and drafted the manuscript with the input of all the authors. All authors approved the final version of the manuscript.

\section{CONFLICT OF INTERESTS}

The authors declare no conflict of interest.

\section{REFERENCES}

1. Neill D. Experimental studies on species relationships in Erythrina (Leguminosae: Papilionoideae). Ann Missouri Bot Gard 1988;75:886-969.

2. Velasquez L, Montoya D, Jimenez A, Murillo W, Mendez J. Genero Erythrina: actualidad en la investigación y perspectivas de desarrollo cientifico. Ibague-Tolima: Sello Editorial Universidad del Tolima; 2019.

3. Powell M, Westley S. editors. Erythrina production and use: a field manual. Hawaii: Nitrogen Fixing Tree Association; 1993.

4. Acero LE. Guia para el cultivo y aprovechamiento del chachafruto o balu, Erythrina edulis triana ex Micheli. Bogota: Convenio Andres Bello; 1996.

5. Biocomercio Sostenible. Estudio de mercado a nivel nacional de productos derivados del chachafruto (Erythrina edulis). Bogota: Instituto de Investigación de Recursos Biologicos Alexander von Humboldt; 2003.

6. Escamilo Cardenas S. El Pajuro (Erythrina edulis) alimento andino en extincion. UNMSM-IIHS 2012;16:16-20.

7. Mejia M, Jaramillo A, Barrera N. Estudios preliminares sobre desarrollo y manejo de la semilla de chachafruto, Erythrina edulis T. Acta Agron 1993;43:57-68.

8. National Research Council. Basul. In: Lost Crop of the Incas: Little known plants of the Andes with promise for worldwide cultivation. Washington, DC: The National Academies Press; 1989. p. 165-72.

9. Barrera N, Acero L, Mejia Leudo M. Erythrina edulis triana ex Micheli. Part II-species descriptions [Internet]. Reforestation, Nurseries and Genetic Resources (RNGR). Available from: https://rngr.net/publications/ttsm/species [Last accessed on 10 Oct 2020]

10. Barrera N, Mejia M. Chachafruto, Balu, Sachaporoto; Erythrina edulis Triana. Pasado, presente y futuro. $3^{\text {rd }}$ ed. Palmira: Universidad Nacional de Colombia; 1998.

11. Acero L. Guia para el cultivo y aprovechamiento del chachafruto o balu Erythrina edulis triana ex Micheli. Bogota: Convenio Andres Bello; 2002.

12. Perez G, Martinez C, Diaz E. Evaluation of the protein quality of Erythrina edulis (balú). Arch Latinoamer Nutr 1979;29:193-207.

13. Association of Official Analytical Chemists. Official method of analysis of A. O. A. C International. $18^{\text {th }}$ ed. Rockville (MD): AOAC International; 2010.

14. Tsugita A, Scheffler J. A rapid method for acid hydrolysis of protein with a mixture of trifluoroacetic acid and hydrochloric acid. Eur J Biochem 1982;124:585-8.

15. Ribeiro B, Andrade P, Silva B, Baptista P, Seabra R, Valentao P. Comparative study on free amino acid composition of wild edible mushroom species. J Agric Food Chem 2008;56:10973-9.

16. Basu S, Das M, Sen A, Choudhury UR, Datta G. Analysis of complete nutritional profile of Amorphophallus campanulatus tuber cultivated in Howrah district of West Bengal, India. Asian J Pharm Clin Res 2014;7:25-9.

17. Imtilemla A, Bareh V, Barbhuiya SB, Sailo L. Preliminary phytochemical screening and in vitro antioxidant activity of the methanolic extract of Lindernia ruellioides (Colsm.) Pennell. Asian J Pharm Clin Res 2020;13:141-6.

18. Arango O, Bolanos P, Ricaurte G, Caicedo M, Guerrero Y. Obtencion de un extracto proteico a partir de harina de chachafruto (Erythrina edulis). Rev Univ Salud 2012;14:161-7.

19. Morales AR. Frutoterapia: nutrición y salud. Madrid: EDAF; 2002.

20. D’Amore C. Evaluación nutricional de harina proteica de Erythrina edulis [dissertation]. Caracas: Universidad Central de Venezuela; 2016.

21. Intiquilla A, Jimenez K, Zavaleta A, Arnao I, Pena C, Chavez E, et al. Erythrina edulis (Pajuro) seed protein: a new source of antioxidant peptides. Nat Prod Commun 2016;11:781-6.

22. Joy JK, Siddhuraju P. Studies on nutritional profile and antioxidant potential of different Dioscorea $\mathrm{sp}$ with Plectranthus rotundifolius. Int J Curr Pharm Res 2017;9:65-74. 